\title{
WATER AND POWER
}


This page intentionally left blank 


\section{WATER}

AND

\section{POWER}

The Conflict

over Los Angeles'

Water Supply in

the Owens Valley

WILLIAM L.KAHRL

University of California Press - BERKELEY •

LOS ANGELES - LONDON 
Cartography by Migel Abalos, Los Angeles

Department of Water and Power

University of California Press

Berkeley and Los Angeles, California

University of California Press, Ltd.

London, England

(C) 1982 by The Regents

of the University of California

First Paperback Printing 1983

\section{Library of Congress Cataloging in Publication Data}

Kahrl, William L.

Water and power.

Bibliography: $p$.

Includes index.

1. Los Angeles (Calif.)-Water-supply.

2. Water-supply-California-Owens Valley. I. Title.

HD4464.L7K33

$333.91^{\prime} 009794^{\prime} 9$

$81-7428$

ISBN 978-0-520-05068-6

Printed in the United States of America

$\begin{array}{lllllllll}16 & 15 & 14 & 13 & 12 & 11 & 10 & 09 & 08\end{array}$

$\begin{array}{lllllllll}14 & 13 & 12 & 11 & 10 & 9 & 8 & 7 & 6\end{array}$

The paper used in this publication meets the minimum requirements of ANSI/NISO Z39.48-1992 (R 1997)

(Permanence of Paper). $@$ 